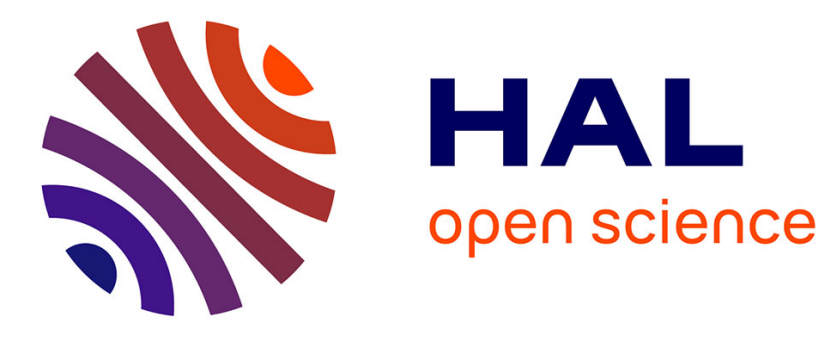

\title{
Regeneration of coked zeolite from PMMA cracking process by ozonation
}

Supaporn Khangkham, Carine Julcour-Lebigue, Somsak Damronglerd, Chawalit Ngamcharussrivichai, Marie-Hélène Manero, Henri Delmas

\section{- To cite this version:}

Supaporn Khangkham, Carine Julcour-Lebigue, Somsak Damronglerd, Chawalit Ngamcharussrivichai, Marie-Hélène Manero, et al.. Regeneration of coked zeolite from PMMA cracking process by ozonation. Applied Catalysis B: Environmental, 2013, vol. 140-141, pp. 396-405. 10.1016/j.apcatb.2013.04.041 . hal-00875900

\section{HAL Id: hal-00875900 https://hal.science/hal-00875900}

Submitted on 23 Oct 2013

HAL is a multi-disciplinary open access archive for the deposit and dissemination of scientific research documents, whether they are published or not. The documents may come from teaching and research institutions in France or abroad, or from public or private research centers.
L'archive ouverte pluridisciplinaire HAL, est destinée au dépôt et à la diffusion de documents scientifiques de niveau recherche, publiés ou non, émanant des établissements d'enseignement et de recherche français ou étrangers, des laboratoires publics ou privés. 


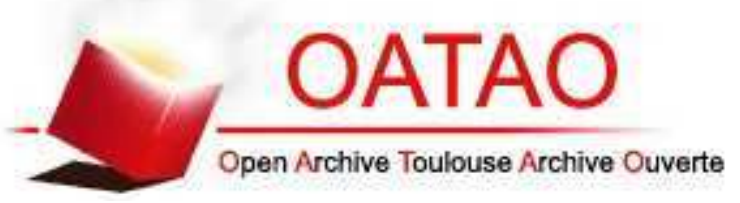

\section{Open Archive TOULOUSE Archive Ouverte (OATAO)}

OATAO is an open access repository that collects the work of Toulouse researchers and makes it freely available over the web where possible.

This is an author-deposited version published in : http://oatao.univ-toulouse.fr/ Eprints ID : 9753

To link to this article : DOI:10.1016/j.apcatb.2013.04.041

URL : http://dx.doi.org/10.1016/j.apcatb.2013.04.041

To cite this version : Khangkham, Supaporn and Julcour-Lebigue, Carine and Damronglerd, Somsak and Ngamcharussrivichai, Chawalit and Manero, Marie-Hélène and Delmas, Henri. Regeneration of coked zeolite from PMMA cracking process by ozonation.(2013) Applied Catalysis B: Environmental, vol. 140-141 . pp. 396-405. ISSN 0926-3373

Any correspondance concerning this service should be sent to the repository administrator: staff-oatao@ listes-diff.inp-toulouse.fr 


\title{
Regeneration of coked zeolite from PMMA cracking process by ozonation
}

\author{
Supaporn Khangkham ${ }^{\mathrm{a}, \mathrm{c}}$, Carine Julcour-Lebigue ${ }^{\mathrm{a}, \mathrm{b}, *}$, Somsak Damronglerd ${ }^{\mathrm{c}}$, \\ Chawalit Ngamcharussrivichai ${ }^{c}$, Marie-Hélène Manero ${ }^{\mathrm{a}}$, Henri Delmas ${ }^{\mathrm{a}}$ \\ a Université de Toulouse, Laboratoire de Génie Chimique, 4 allée Emile Monso - BP 84234, 31030 Toulouse Cedex 4, France \\ ${ }^{\mathrm{b}}$ CNRS, Laboratoire de Génie Chimique, 31030 Toulouse, France \\ ' Department of Chemical Technology, Faculty of Science, Chulalongkorn University, Bangkok 10330, Thailand
}

Keywords:

Coke

Ozone

ZSM-5

Acid sites

Plastic wastes

\begin{abstract}
A B S T R A C T
Regeneration of coked ZSM-5 zeolite was performed by oxidation with ozone at low temperature range $\left(<150^{\circ} \mathrm{C}\right)$ so that to restore catalytic activity. Physicochemical properties of the samples were characterized by several techniques: thermogravimetry (nature of coke deposit), elemental analysis (carbon content), porosimetry (surface area and pore size), ammonia temperature-programmed desorption and pyridine adsorption followed by infrared spectroscopy (acidity). Reactions were carried out at various temperatures, gas hourly space velocities and inlet concentrations of ozone. They showed that partially coked samples (containing $3 \mathrm{wt} . \%$ of C) can be successfully regenerated by ozone with carbon removal up to $80 \%$.

Carbon removal is improved by increasing the inlet ozone concentration in the range $16-50 \mathrm{~g} / \mathrm{m}^{3}$, with almost linear trend, and by increasing time on stream until it plateaus after $2 \mathrm{~h}$. Coke oxidation with $\mathrm{O}_{3}$ starts at low temperature and exhibits an optimum at about $100^{\circ} \mathrm{C}$. At higher temperatures, the rate of ozone decomposition becomes much faster than its pore diffusion rate, so that radical species are no longer available for the coke deposit within the particles and the overall oxidation yield decreases. Indeed, catalytic decomposition of ozone is found to occur significantly above $100{ }^{\circ} \mathrm{C}: \mathrm{O}_{3}$ decomposition reaches $90 \%$ with fresh ZSM-5 catalyst. Thus regeneration of coked zeolite particles involves both complex chemical reactions (coke oxidation and $\mathrm{O}_{3}$ decomposition to active but unstable species) and transport processes (pore diffusion to the internal coked surface).

Ozonation can restore both textural and acidic properties, allowing the catalyst to almost recover its initial activity in poly(methyl metacrylate) cracking. The activity results are well correlated with the carbon removal efficiency.
\end{abstract}

\section{Introduction}

Zeolites are used in many industrial and petrochemical processes because of their unique properties of molecular sieving, acidity, high thermal stability, and shape selectivity [1]. For example, FAU-type zeolite, e.g. Y and Ultrastable Y zeolite, is extensively applied as catalyst in fluid catalytic cracking (FCC). In this process, MFI-type zeolite, e.g. ZSM-5, is frequently used as FCC catalyst additive either in the form of separate particles or within a composite to control product yield and/or to improve octane number [2]. Moreover, zeolites, and ZSM-5 in particular, are also applied

\footnotetext{
* Corresponding author at: Université de Toulouse, Laboratoire de Génie Chimique, 4 allée Emile Monso - BP 84234, 31030 Toulouse Cedex 4, France. Tel.: +33 534323709; fax: +33534323697

E-mail address: carine.julcour@ensiacet.fr (C. Julcour-Lebigue).
}

in recycling of plastic wastes to provide more valuable products: monomer and/or gas and liquid which can be reutilized as chemical reagents or fuels $[3,4]$. Previous results showed that MMA recovery by cracking of PMMA was successfully achieved on a zeolite fixed bed at temperatures below $300^{\circ} \mathrm{C}$ [5]. Such temperature is of significant advantage as compared to conventional thermal processes $\left(400-450^{\circ} \mathrm{C}\right)$, as proposed by Kaminsky et al. [6-8] using fluidized bed reactors or more recently by Lopez et al. [9] using a spouted bed reactor.

Even if zeolite catalysts produce less coke than other materials, it is still a common feature which requires efficient and low-cost regeneration techniques for the process economy. Deposition of carbonaceous residues blocks the access of pores to the reacting molecules and/or poisons active acid catalytic sites [10-15]. Besides the loss of activity and/or selectivity, coking can also reduce heat transfer in the reactor, while increasing pressure drop and possibly even plugging the reactor. 
The spent zeolites are traditionally regenerated by several methods, such as thermal treatment, or reaction with oxygen or nitrous oxide-containing mixtures [4,11-14].

Oxidative treatments using oxygen usually operate above $400^{\circ} \mathrm{C}$ and may result into irreversible chemical modification of the zeolites through hydrothermal process with generated water vapour $[4,14,16]$.

Regeneration by ozone is an attractive low temperature process due to the high oxidizing activity of this compound [17]. This technique is therefore particularly interesting to preserve the structure of the zeolite catalyst and to prevent dealumination. Copperthwaite et al. [16] showed that ozone-enriched oxygen treatment can restore activity of ZSM-5 zeolites used for methanol conversion under mild conditions $\left(150^{\circ} \mathrm{C}\right)$, while a temperature of about $450^{\circ} \mathrm{C}$ was necessary with oxygen only. The main difference observed between the two restored catalysts lay in a higher selectivity towards light gases in the $\mathrm{C}_{2}-\mathrm{C}_{4}$ fraction for the ozonized samples (with reduced methane, $\mathrm{C}_{5}+$ and aromatic yields).

From FT-IR study of coked HY zeolite regeneration, Mariey et al. [18] also concluded that ozone was effective at $170^{\circ} \mathrm{C}$ or less (as compared to $500^{\circ} \mathrm{C}$ for oxygen) and preserved the framework of samples with a low Si/Al ratio.

However using coked $\mathrm{Y}$ zeolites in the form of $1 / 16$ in. diameter extrudates, Hutchings et al. [19] found that ozone treatment at $200^{\circ} \mathrm{C}$ only removed coke on the outer surface of the pellets and regeneration obeyed a shrinking core mechanism with pore diffusion control.

In the present work, regeneration of coked ZSM-5 extrudates is studied using an ozone-enriched oxygen stream at low temperature, in the range $20-150^{\circ} \mathrm{C}$. The objective of this work is to understand the interactions between ozone and spent zeolite and to find the best operating conditions for coke removal and catalyst activity restoration. In the following, the term "coke" will refer to all carbonaceous materials which are located on the zeolite, irrespective of their chemical nature and molecular weight [20].

\section{Materials and methods}

\subsection{Material}

ZSM- 5 zeolite was provided by Zeolyst International in the form of ca. $3 \mathrm{~mm} \times 10 \mathrm{~mm}$ extrudates pelletized with $20 \mathrm{wt} . \%$ of aluminium oxide. The pure $\mathrm{ZSM}-5$ phase was given with a $\mathrm{SiO}_{2} / \mathrm{Al}_{2} \mathrm{O}_{3}$ molar ratio of 23 .

The extrudates were used as catalyst for the cracking of poly(methyl methacrylate) (PMMA) in a fixed bed reactor operating at 1 bar and $250-300^{\circ} \mathrm{C}$. Distribution of coke deposit varied axially along the bed, with a higher amount at the top of the reactor close to the PMMA feed. Nature of the deposit also differed: top particles were coated with a dense, shiny black, layer that eventually stuck them together, while bottom particles of grey colour kept well separate. Particle samples from both locations were collected for regeneration tests.

PMMA was supplied by Siam Cement Group company, as 3-5 mm scrap particles. Its average molecular weight was about $100,000 \mathrm{~g} / \mathrm{mol}$.

\subsection{Characterization of the zeolites}

Physicochemical properties of the coked and regenerated catalysts were evaluated by several techniques and compared to those of fresh zeolites.

Textural properties, which are essential to evaluate the role of internal mass transfer in the effective burn-off rate, were measured by $\mathrm{N}_{2}$ adsorption at $77 \mathrm{~K}$ on a Micromeritics ASAP 2010 and by mercury intrusion on a Micromeritics AUTOPORE IV. Prior to $\mathrm{N}_{2}$ sorption, the solid samples were degassed at $200^{\circ} \mathrm{C}$ (this temperature being selected to avoid coke removal). The specific surface area was calculated from BET plot at relative pressures between 0.01 and 0.2 [21]. The mesoporous and microporous volumes were estimated from gas porosimetry measurements according to Barrett-Joyner-Halenda [22] and Horvath-Kawazoe [23] methods respectively. The macroporous volume ( $50 \mathrm{~nm}<$ pore diameter $<30 \mu \mathrm{m}$ ) and skeletal density were evaluated from mercury porosimetry.

Chemical characterization was done using different techniques.

Thermogravimetry coupled with infrared analysis of released gases (TGA-IR) was used to qualify the nature of the carbonaceous deposit. These analyses were performed on a Q50 thermobalance (TA Instruments) under controlled atmosphere (nitrogen). The samples were heated at $10^{\circ} \mathrm{C} / \mathrm{min}$ from room temperature to $1000^{\circ} \mathrm{C}$, including $60 \mathrm{~min}$ plateau at $120^{\circ} \mathrm{C}$ to remove physisorbed water.

The amount of carbon in the aged/regenerated catalysts was determined by a CHN elemental analyzer (flash combustion) using about $20 \mathrm{mg}$ of crushed sample.

Particle cross-sections were observed by scanning electron microscopy (Leo $435 \mathrm{VP}$ ) coupled with energy dispersive X-ray (Oxford INCA 200) analysis to profile elemental carbon content within the particles.

Finally the acidity of zeolite catalysts, which is usually correlated with their activity in $\mathrm{C}-\mathrm{C}$ bond cracking [3], was evaluated by two complementary techniques:

- ammonia temperature-programmed desorption ( $\left.\mathrm{NH}_{3}-\mathrm{TPD}\right)$ carried out on a chemisorption analyzer (Micromeritics AutoChem II 2920) equipped with a thermal conductivity detector,

- pyridine adsorption/desorption followed by infrared (IR) spectroscopy (Nicolet NEXUS).

$\mathrm{NH}_{3}$-TPD first provided information about the global acidity of the zeolites. Crushed samples $(50 \mathrm{mg}$ ) were outgassed under an argon flow $(50 \mathrm{ml} / \mathrm{min})$ by heating with a rate of $10^{\circ} \mathrm{C} / \mathrm{min}$ up to $400^{\circ} \mathrm{C}$, and cooled back to ambient prior to $\mathrm{NH}_{3}$ saturation. After removal of physisorbed $\mathrm{NH}_{3}\left(\right.$ at $50^{\circ} \mathrm{C}$ ), a temperature ramp rate of $10^{\circ} \mathrm{C} / \mathrm{min}$ was applied up to $800^{\circ} \mathrm{C}$ under argon flow $(50 \mathrm{ml} / \mathrm{min})$. The free acid sites were evaluated from subtraction of TPD spectra with and without the preliminary saturation of the zeolite with $\mathrm{NH}_{3}$. From deconvolution of the resulting $\mathrm{NH}_{3}$-TPD spectrum, three peaks were also distinguished, each following a gaussian distribution. They corresponded to weak (low desorption temperature, $\left.140-150^{\circ} \mathrm{C}\right)$, medium $\left(235-245^{\circ} \mathrm{C}\right.$ ) and strong (high desorption temperature $>450^{\circ} \mathrm{C}$ ) acid sites, respectively [24]. To determine the total amount of acid sites, an amorphous silica-alumina (ASA) which known amount of total acid sites $\left(0.55 \mathrm{mmol} \mathrm{g}^{-1}\right.$ [25]) was used as reference material.

Pyridine adsorption/desorption allowed the distinction between Brønsted and Lewis acid sites, due to the narrow character and high extinction coefficient of the typical IR bands [26]. Crushed zeolite samples (10-30 mg) were pressed into thin wafers and pretreated under flowing air at $450^{\circ} \mathrm{C}$ overnight and then under vacuum. Excess pyridine was adsorbed at $150^{\circ} \mathrm{C}$ and after a few minutes physisorbed pyridine was removed under vacuum $(1 \mathrm{~h})$. The concentration of Brønsted and Lewis acid sites able to retain pyridine at $150^{\circ} \mathrm{C}$ was estimated from the surface of IR bands at $1545 \mathrm{~cm}^{-1}$ and $1455 \mathrm{~cm}^{-1}$, respectively. Subsequent desorption analyses were performed at 


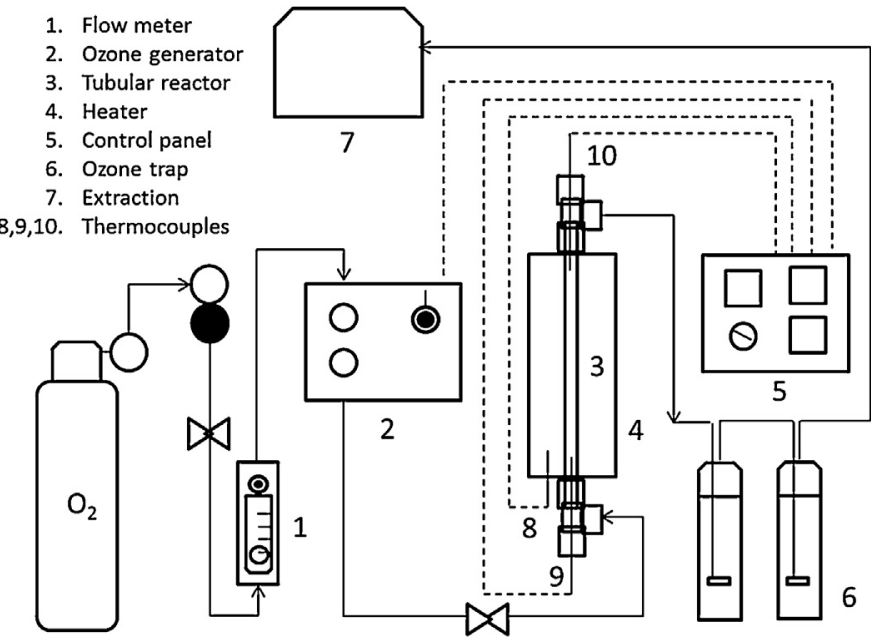

Fig. 1. Schematic diagram of the experimental set-up for the regeneration of coked zeolites.

$250^{\circ} \mathrm{C}, 350^{\circ} \mathrm{C}$ and $450^{\circ} \mathrm{C}$ to estimate the strength of acid sites [27].

\subsection{Experimental set-up and procedure for regeneration of coked zeolites}

Ozonation of coked ZSM-5 samples ( $800 \mathrm{mg}$ ) was performed in a glass tube reactor ( $4 \mathrm{~mm}$ i.d., $18 \mathrm{~cm}$ length) at temperatures varying from $20^{\circ} \mathrm{C}$ to $150^{\circ} \mathrm{C}$. It was inserted in a heated stainless steel cylinder whose temperature was adjusted by a PID controller. A laboratory ozone generator (HTU-500 ozone generator, Azcozon) was used to produce ozone from pure oxygen, in the range of concentration $16-50 \mathrm{~g} / \mathrm{m}^{3}$.

The schematic diagram of the experimental set-up is given in Fig. 1.

Spent zeolite particles of about $3 \mathrm{~mm}$ in diameter were loaded in the reactor after half part was cut and kept as reference. The sample was first heated under oxygen flow (up-flow mode, flow rate from 12.7 to $69.9 \mathrm{l} / \mathrm{h}$ ) until desired temperature was reached Then the gas flow was switched to $\mathrm{O}_{3} / \mathrm{O}_{2}$ mixture $\left(16-50 \mathrm{~g} / \mathrm{m}^{3}\right.$ of ozone content). Time on stream (TOS) was varied from $0.5 \mathrm{~h}$ to $4 \mathrm{~h}$. Inlet and outlet ozone concentrations were measured by the potassium iodide-trap method (IOA Standardized Procedure 001/96).

After treatment, particles were crushed and mixed for carbon analysis by flash combustion technique (same for reference half pellets).

\subsection{Experimental set-up and procedure for activity tests}

PMMA cracking tests were carried out in $100 \mathrm{ml}$ batch reactor (Parr instrument) using $0.4 \mathrm{~g}$ of crushed zeolite extrudate and $40 \mathrm{~g}$

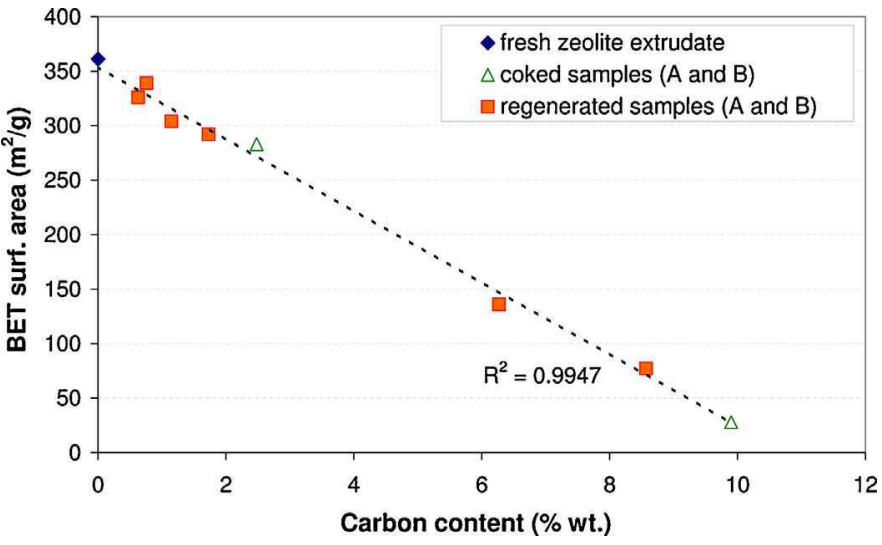

Fig. 2. Evolution of BET surface area of zeolite extrudates as a function of carbon content.

of PMMA. Pure nitrogen was continuously flowed through the reactor for $5 \mathrm{~min}$ in order to eliminate oxygen. Then the gas inlet and outlet were closed and the reactor temperature was set to $300^{\circ} \mathrm{C}$. The reaction was subsequently performed for $120 \mathrm{~min}$ at $300^{\circ} \mathrm{C}$ under autogenous pressure, resulting in gas, liquid and solid products. After cooling and degassing, the reactor content was weighted again to give the gas yield. Then solid and liquid products were separated. The solid residual was washed with $50 \mathrm{ml}$ of MMA, then centrifuged and dried at $80^{\circ} \mathrm{C}$ for $24 \mathrm{~h}$ to remove all interstitial liquid before weighing. The liquid product was distilled in a rotary evaporator at $95^{\circ} \mathrm{C}$ under vacuum pressure (200 mbar) to obtain the light fraction.

\section{Results and discussion}

\subsection{Physicochemical properties of zeolite extrudate samples}

Regeneration experiments were performed on two different lots of coked ZSM-5 extrudates:

- bottom particles from continuous PMMA cracking reactor, containing $2-4 \%$ of carbon (sample $A$ ),

- top particles, containing $9-11 \%$ of carbon (sample B).

\subsubsection{Surface area and porosity}

Typical textural properties of coked and regenerated samples are given in Table 1 and compared to those of fresh zeolite.

Coke deposition was found to occur in both micro- and mesopores, resulting in a sharp, almost linear, decrease of the surface area with respect to carbon content (cf. Fig. 2). The most severely coked sample exhibited nearly no microporosity.

The specific surface area of the partially regenerated samples aligned with the previous data in Fig. 2, showing that the ozone treatment restored the textural properties of the zeolite, without any significant structural modification. The sample $A$ recovered a

Table 1

Physical characteristics of zeolite samples.

\begin{tabular}{|c|c|c|c|c|}
\hline & Carbon content (wt.\%) & BET surface area $\left(\mathrm{m}^{2} / \mathrm{g}\right)$ & Microporous volume $\left(\mathrm{cm}^{3} / \mathrm{g}\right)$ & Mesoporous volume $\left(\mathrm{cm}^{3} / \mathrm{g}\right)$ \\
\hline Sample A & 2.5 & 283 & 0.11 & 0.15 \\
\hline (Partially) regenerated sample $\mathrm{A}\left(95^{\circ} \mathrm{C}, 1 \mathrm{~h}\right)$ & 1.2 & 304 & 0.12 & 0.15 \\
\hline (Partially) regenerated sample $\mathrm{A}\left(140^{\circ} \mathrm{C}, 2 \mathrm{~h}\right)$ & 1.7 & 292 & 0.11 & 0.19 \\
\hline (Partially) regenerated sample $\mathrm{A}\left(95^{\circ} \mathrm{C}, 2 \mathrm{~h}\right)$ & 0.8 & 339 & 0.13 & 0.17 \\
\hline (Partially) regenerated sample $\mathrm{A}\left(95^{\circ} \mathrm{C}, 4 \mathrm{~h}\right)$ & 0.6 & 326 & 0.13 & 0.16 \\
\hline Fresh zeolite extrudate & - & 361 & 0.13 & 0.18 \\
\hline (Partially) regenerated sample $\mathrm{B}\left(95^{\circ} \mathrm{C}, 4 \mathrm{~h}\right)$ & 6.3 & 136 & 0.05 & 0.11 \\
\hline (Partially) regenerated sample $\mathrm{B}\left(140^{\circ} \mathrm{C}, 2 \mathrm{~h}\right)$ & 8.6 & 77 & 0.03 & 0.11 \\
\hline Sample B & 9.9 & 28 & 0.01 & 0.09 \\
\hline
\end{tabular}


Table 2

Elemental analysis from EDX spectroscopy and carbon content from flash combustion.

\begin{tabular}{|c|c|c|c|c|}
\hline & Fresh zeolite extrudate & Sample A & Sample B & (Partially) regenerated sample $\mathrm{A}\left(95^{\circ} \mathrm{C}, 2 \mathrm{~h}\right)$ \\
\hline \multicolumn{5}{|l|}{ Elemental analysis from EDX (wt.\%/at.\%) } \\
\hline $\mathrm{C}$ & - & $3.7 / 6.0$ & $9.2 / 14.6$ & a \\
\hline $\mathrm{O}$ & $50.1 / 63.6$ & $51.7 / 62.8$ & $46.4 / 55.0$ & $51.9 / 65.2$ \\
\hline $\mathrm{Al}$ & $14.0 / 10.5$ & $12.7 / 9.1$ & $12.8 / 9.0$ & $13.5 / 10.0$ \\
\hline $\mathrm{Si}$ & $35.9 / 25.9$ & $31.9 / 22.1$ & $31.6 / 21.4$ & $34.6 / 24.8$ \\
\hline Carbon content from flash combustion (wt.\%) & - & 3.0 & 9.9 & 0.8 \\
\hline
\end{tabular}

a Below the limit of detection.

similar pore size distribution as the fresh catalyst after $2 \mathrm{~h}$ of ozonation at $95^{\circ} \mathrm{C}$, while at higher regeneration temperature $\left(140^{\circ} \mathrm{C}\right)$ only its mesoporous volume was fully restored.

\subsubsection{Elemental analysis}

The elemental profile along the cross sectional area of the particles was analyzed by SEM/EDX for both coked samples (Fig. 3): the carbonaceous deposit was found well distributed across the extrudate, with the exception of a narrow zone of higher concentration at the very outer surface (depth $<50 \mu \mathrm{m}$ ).

The mean carbon contents estimated from EDX spectroscopy were in accordance with those determined from flash combustion of the materials (Table 2), with a much higher value for coked sample $B$. The $\mathrm{Si} / \mathrm{Al}$ atomic ratio of about 2.5 also agreed well with the theoretical value (accounting for the presence of alumina binder) and kept unchanged after regeneration (no dealumination).

\subsubsection{Thermogravimetry}

The thermograms of coke samples (realized under $\mathrm{N}_{2}$ ), as well as the identification of evolved gases from IR spectroscopy, are given in Fig. 4.

The amount of physisorbed water decreased logically from fresh zeolite (9.5wt.\%) to sample A (5.8\%) and sample B (3.2\%). Then three distinct stages were observed for coked samples after the $120^{\circ} \mathrm{C}$ plateau. A first weight loss of less than $1 \%$ was observed from $120^{\circ} \mathrm{C}$ to $250-300^{\circ} \mathrm{C}$ corresponding mainly to the release of water: it might be due to coordinated water, as it was also observed on the fresh zeolite. $\mathrm{CO}_{2}$ emission then started to increase with a maximum intensity observed between $400^{\circ} \mathrm{C}$ and $600^{\circ} \mathrm{C}$, and was detected up to the end. CO release came later, mainly after $600^{\circ} \mathrm{C}$. Some compounds were only detected for sample $B$, namely MMA (with a narrow peak around $405^{\circ} \mathrm{C}$ ), methanol (around the same temperature), methane $\left(385-665^{\circ} \mathrm{C}\right)$ and ethylene $\left(425-585^{\circ} \mathrm{C}\right)$. This difference might be attributed to a PMMA rich layer coating the top particles. It should be also noticed that the corresponding rate of weight loss (from $300^{\circ} \mathrm{C}$ to $450^{\circ} \mathrm{C}$ ) was much higher than that of other stages.

Some complementary TG analyses were also carried out under air. They showed that the sample weight decreases up to $700^{\circ} \mathrm{C}$, with a total weight loss after the $120^{\circ} \mathrm{C}$ plateau of $6.5 \%$ and $17.3 \%$ for samples $A$ and $B$, respectively (for a respective carbon content of $4.1 \%$ and $11.5 \%$ ).

The coke deposit is usually qualified as "soft coke" or "hard coke", depending to its ability to be volatilized/decomposed under nitrogen and oxygen. Following the work of Wang and Manos [28], the amount of coke precursors or "soft coke" can be roughly estimated from the weight loss observed between $250-300^{\circ} \mathrm{C}$ and $600{ }^{\circ} \mathrm{C}$ under $\mathrm{N}_{2}$, resulting in $1.5 \%$ and $9.5 \%$ for samples $A$ and $B$ respectively. The amount of "hard coke" is obtained from the difference between the total weight loss under air and the weight loss up to $600^{\circ} \mathrm{C}$ under $\mathrm{N}_{2}: 4.2 \%$ and $7.3 \%$ for samples $A$ and $B$ respectively.

According to the conclusions of Elordi et al. on the cracking of polyethylene [24], "soft coke" would be mainly deposed outside the zeolite crystals, while "hard coke" would be formed in the interior of crystalline channels. However the location of the carbonaceous deposits depends also on the hydrocarbon used as the coke-forming agent [20]. Here the reduction of mesopores

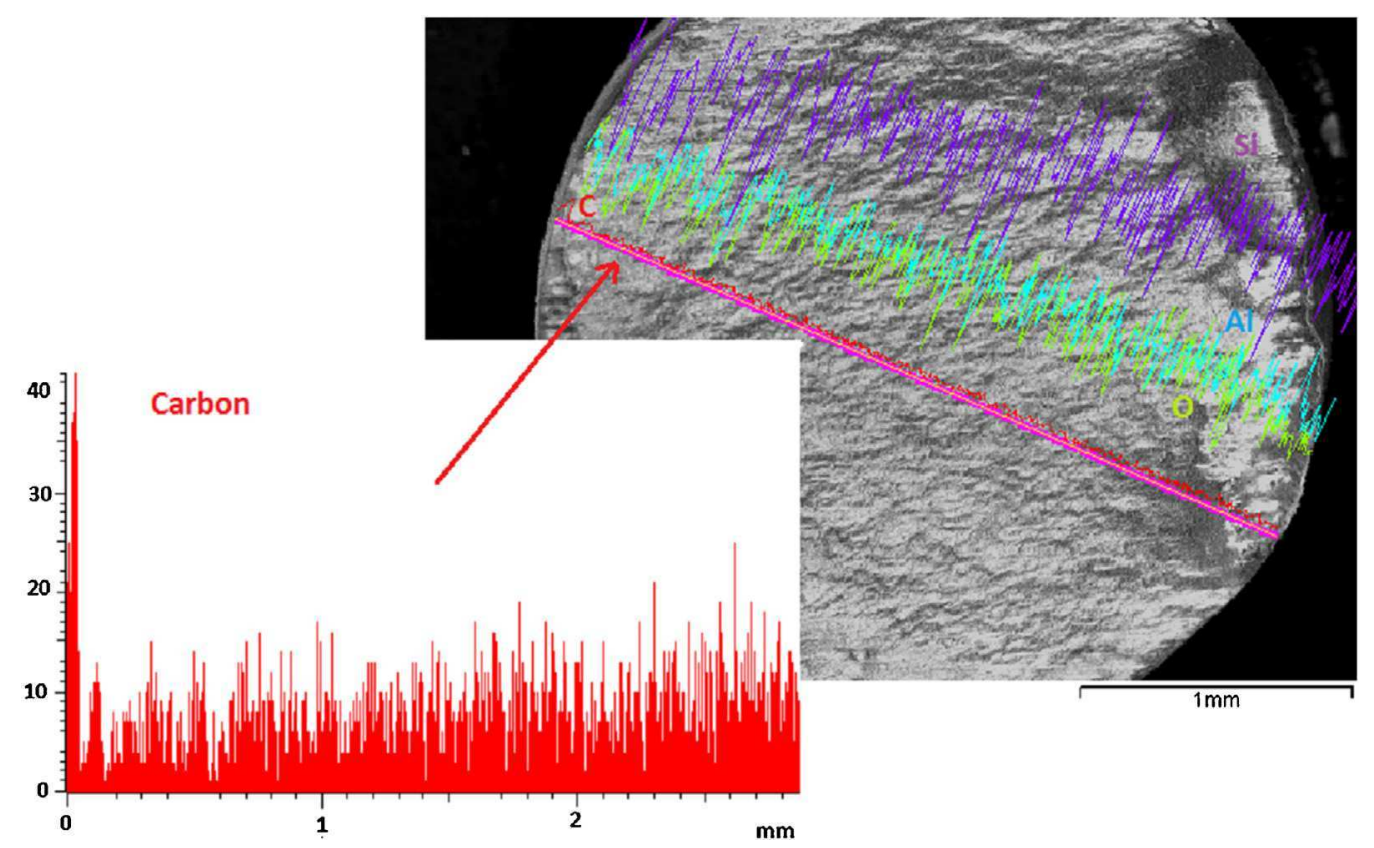

Fig. 3. Elemental carbon profile a on a cross-section of extrudate $A$. 

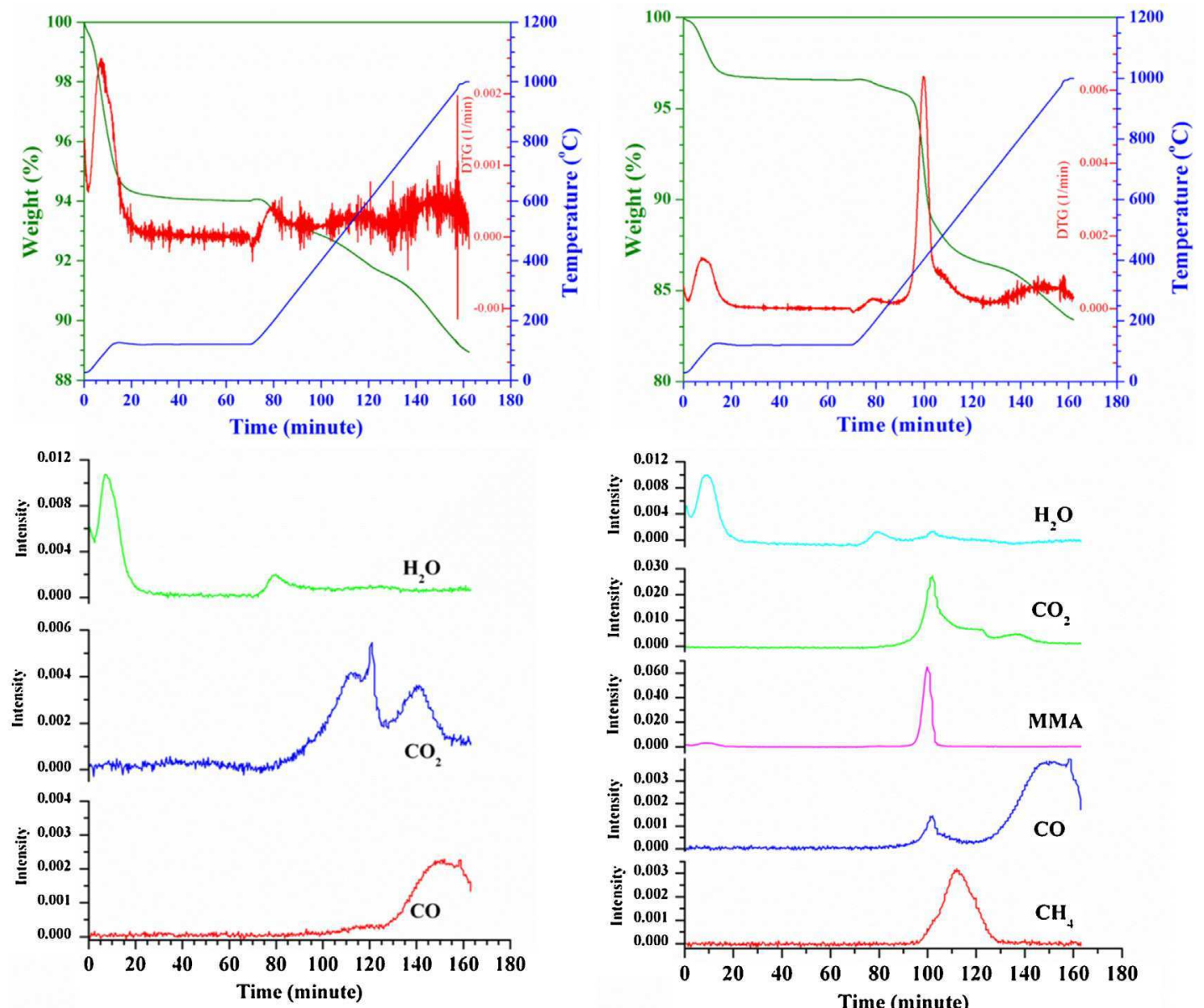

(a)

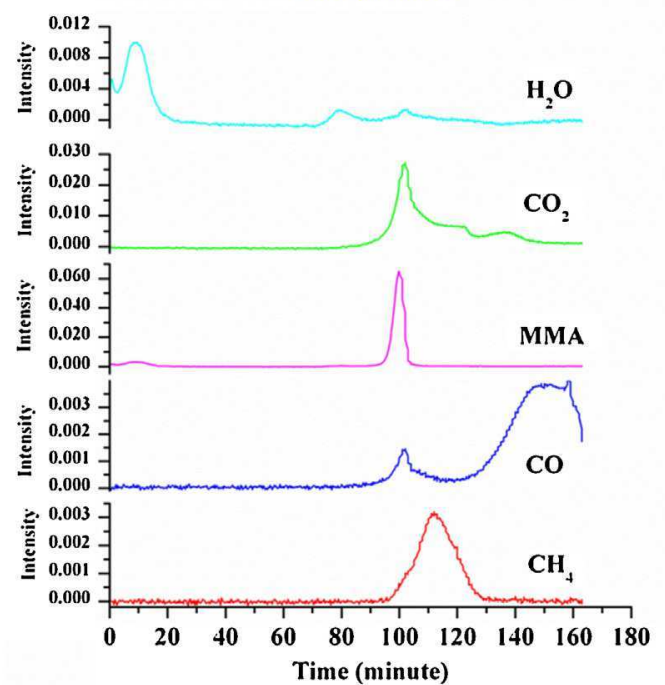

(b)

Fig. 4. Thermograms of coked zeolites under $\mathrm{N}_{2}$, along with identification of evolved gases from IR spectroscopy: (a) sample A and (b) sample B.

seemed better correlated with the increase of "hard coke", and that of micropores with the increase of "soft coke".

\subsection{Regeneration of the catalysts by ozonation}

For sample $A$, very high carbon conversion up to $80 \%$ could be achieved in the investigated conditions (see Fig. 6). For sample $B$, performance was more modest ( $35 \% \mathrm{C}$ removal), mainly due to the fact that the particles were coated by a PMMA rich layer, as found by TG/IR, that limits the access of ozone to the zeolite. Therefore parametric study was performed with sample A only.

\subsubsection{Effect of operating parameters}

Carbon removal was found to increase almost proportionally with the inlet concentration of ozone in the investigated range, as seen in Fig. 5.

As expected, conversion was improved by increasing time on stream, but it seemed to reach a plateau after $2 \mathrm{~h}$ (Fig. 6a). The effect of temperature, depicted in Fig. 6b, is more complex as an optimum was found at about $100{ }^{\circ} \mathrm{C}$ regardless time on stream, due to some competition effect between the chemical and mass transport kinetics involved, as it will be explained below.

Measurements of ozone concentration at the reactor outlet showed that less than $10 \%$ of the ozone was thermally decomposed at $100^{\circ} \mathrm{C}$ (in an empty tube), while over fresh ZSM-5 extrudate, ozone decomposition could reach more than $90 \%$ along the string reactor, as seen in Fig. 7. Outlet ozone concentration was also analyzed on the beginning of the decoking reaction (0-30 min): lower ozone decomposition was observed with the coked catalyst below $100^{\circ} \mathrm{C}$ due to its lower activity.

Optimal conditions were then further investigated by varying operating parameters at about $100^{\circ} \mathrm{C}$ for the same amount of ozone provided to the sample.

Similar results were obtained when increasing the gas flow rate from 12.7 to $45.4 \mathrm{l} / \mathrm{h}$ (and decreasing time on stream accordingly from $2 \mathrm{~h}$ to $33 \mathrm{~min}$ ): about $40 \% \mathrm{C}$ removal (for an inlet $\mathrm{O}_{3}$ concentration of $19 \mathrm{~g} / \mathrm{m}^{3}$ ). In comparison, conversion was $24.7 \%$ for $12.7 \mathrm{l} / \mathrm{h}$ and $30 \mathrm{~min}$ TOS (other conditions being equal). Increasing the gas flow rate reduced the ozone concentration gradient inside the reactor, which compensated for the diminution of TOS.

Furthermore, carbon removal was decreased when using a higher gas flow rate with lower ozone content (at same total ozone input): $55.8 \%$ for $12.7 \mathrm{l} / \mathrm{h}$ and $48.2 \mathrm{~g} / \mathrm{m}^{3}$ (over $30 \mathrm{~min}$ ) against $32.9 \%$ for $41.3 \mathrm{l} / \mathrm{h}$ and $13.7 \mathrm{~g} / \mathrm{m}^{3}$. This confirms that the decoking rate increases with ozone concentration.

\subsubsection{Carbon profiles in the reactor and in the particles}

Axial coke conversion profiles were measured at about $100^{\circ} \mathrm{C}$ after $1 \mathrm{~h}$ of reaction by dividing the reactor into 5 zones (containing 3-4 pellets each) and analyzing separately their residual carbon content (which was compared to that of the corresponding reference half pellets). As usual, each separate lot of particles was crushed and homogenized prior to flash combustion analysis. Fig. 8 shows that carbon conversion varied slightly along the reactor for sample $A$, from $59 \%$ to $50 \%$, and from $26 \%$ to $14 \%$ for sample B. Surprisingly, the axial gradient of ozone concentration appears thus to 


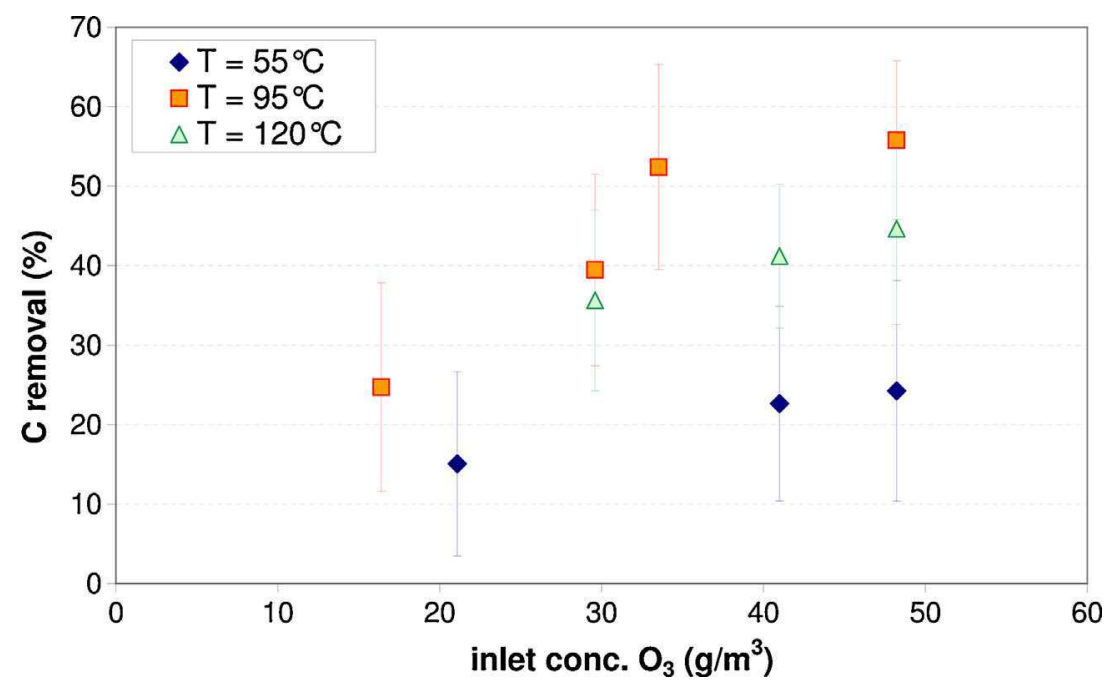

Fig. 5. Evolution of carbon removal as a function of inlet $\mathrm{O}_{3}$ concentration at different outlet temperatures $\left(Q_{G}=12.7 \mathrm{l} / \mathrm{h}, \mathrm{TOS}=30 \mathrm{~min}\right)$.

have a rather moderate impact on the conversion. This result may be in fact explained by the existence of a temperature gradient of about $10^{\circ} \mathrm{C}$ along the reactor ( $\mathrm{C}$ removal being improved by an increase of temperature in this range). As abovementioned, the different regeneration yields of samples $A$ and $B$ are mainly due to the different types of carbonaceous deposit on their surface, since multiplying TOS by a factor 4 only increased the mean carbon removal of sample $B$ to $35 \%$ conversion.

Finally, Fig. 9 displays the photos of partially regenerated sample $A$ for two outlet temperatures: $95^{\circ} \mathrm{C}$ and $140^{\circ} \mathrm{C}$ (after $1 \mathrm{~h}$ TOS). On
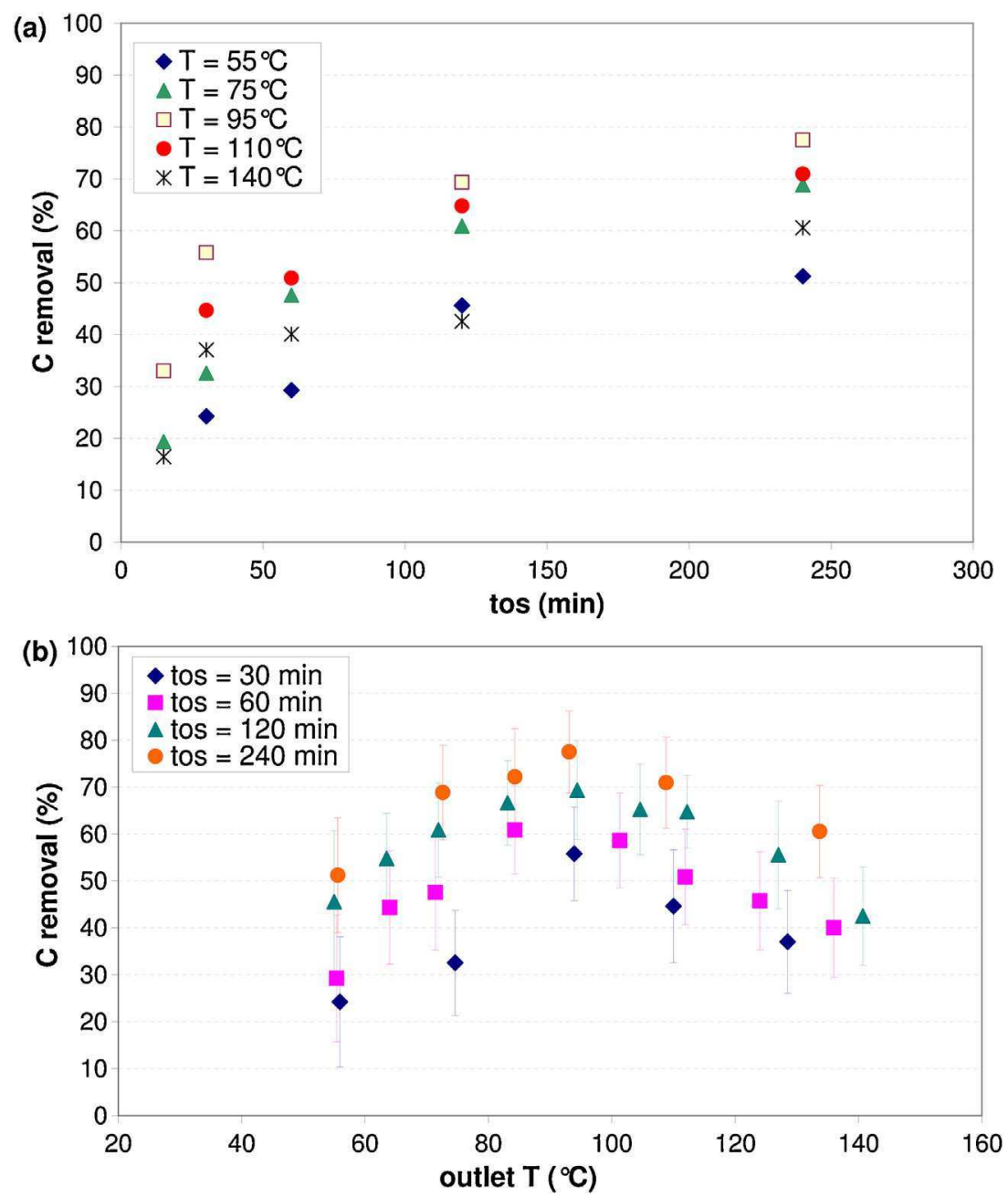

Fig. 6. Evolution of carbon removal as a function of (a) time on stream and (b) outlet temperature $\left(Q_{\mathrm{G}}=12.7 \mathrm{l} / \mathrm{h}, C_{\mathrm{O}_{3}, \text { in }}=48 \mathrm{~g} / \mathrm{m}^{3}\right)$. 


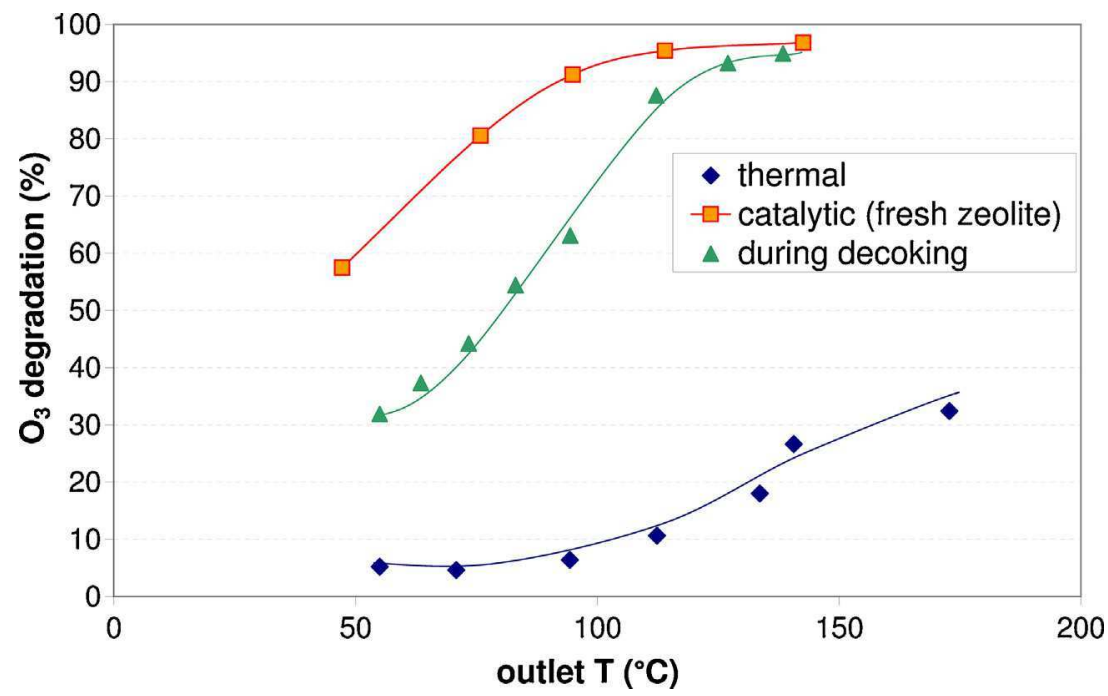

Fig. 7. Ozone decomposition as a function of outlet temperature $\left(Q_{G}=12.71 / \mathrm{h}, C_{\mathrm{O}_{3} \text {, in }}=48 \mathrm{~g} / \mathrm{m}^{3}\right)$.

the left are shown the reference half pellets, at the centre the outer surface of the ozonized samples and on the right their cross-section cutaway.

At the highest temperature, decoking takes place according to a shrinking core process as already observed by Hutchings et al. [19]: cross-section views (c) show a black core of coked catalyst surrounded by a very white layer of regenerated catalyst.

At $140^{\circ} \mathrm{C}$ the rate of ozone decomposition is much faster than its diffusion rate. Radical species generated are known to have a short lifetime, and they should be consumed (either by reaction with remaining coke in the close vicinity or by radical recombination reactions) before reaching the coke deposit within the particles. This makes the overall process highly limited by diffusion.

At $100^{\circ} \mathrm{C}$, the smaller difference in grey level contrast between the core and the surface of the particles was due to the slower ozone decomposition rate: ozone had more time to diffuse within the particle before being converted into highly reactive species. Therefore the overall carbon removal is improved as shown in Fig. 6.

\subsection{Activity assessment}

The regenerated zeolites were subsequently examined for acid properties and activity in PMMA degradation in batch reactor.

\subsubsection{Acid properties}

As abovementioned, acid sites are known to promote $\mathrm{C}-\mathrm{C}$ bond scission. Moreover, the strength and nature (Brønsted or Lewis) of the acid sites influence both the activity and selectivity of the cracking reaction: the stronger the sites, the lighter hydrocarbons obtained $[3,29]$.

From $\mathrm{NH}_{3}$-TPD analysis, a distribution of the acid sites according to their strength could be provided: Fig. 10a and b gives, for different regeneration conditions, the relative amount of each category of acid sites (weak, medium and strong) with respect to the total amount of acid sites in the fresh ZSM-5 extrudate $\left(2.09 \mathrm{mmol} \mathrm{g}^{-1}\right.$ from calibration with ASA).

With respect to fresh zeolite, the amount of sample $A$ acid sites decreased by about a factor 3 , almost regardless of their strength.

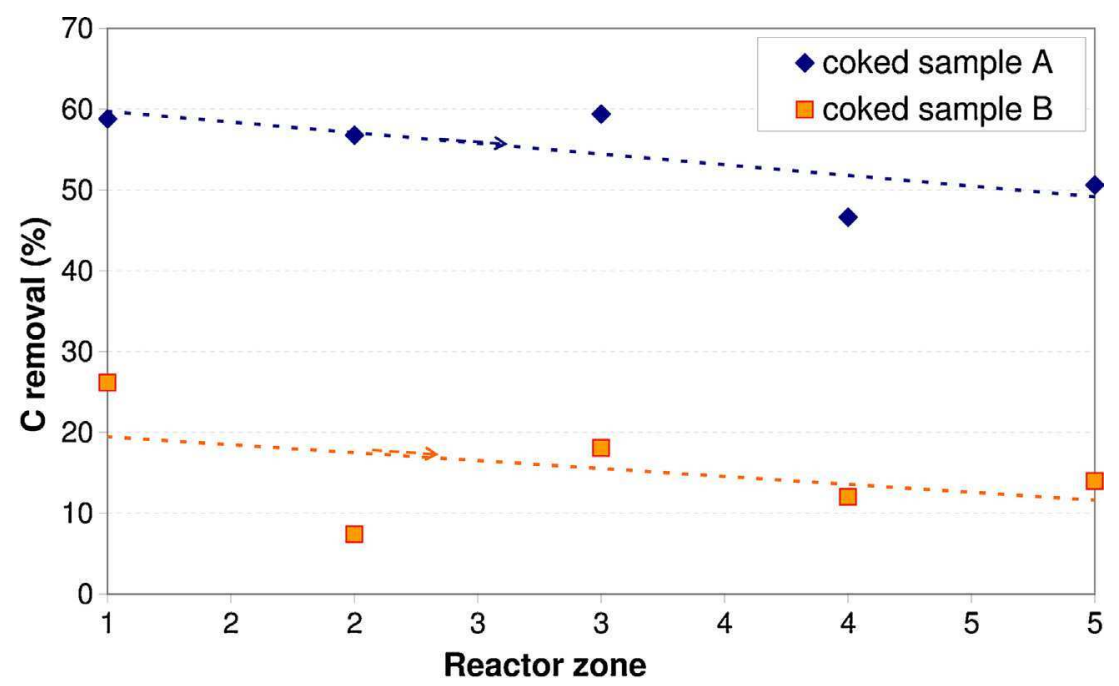

Fig. 8. Axial profiles of carbon removal $\left(T_{\text {oulet }}=95^{\circ} \mathrm{C}, Q_{\mathrm{G}}=12.7 \mathrm{l} / \mathrm{h}, \mathrm{C}_{\mathrm{O}_{3} \text {, in }}=48 \mathrm{~g} / \mathrm{m}^{3}, \mathrm{TOS}=1 \mathrm{~h}\right)$ 

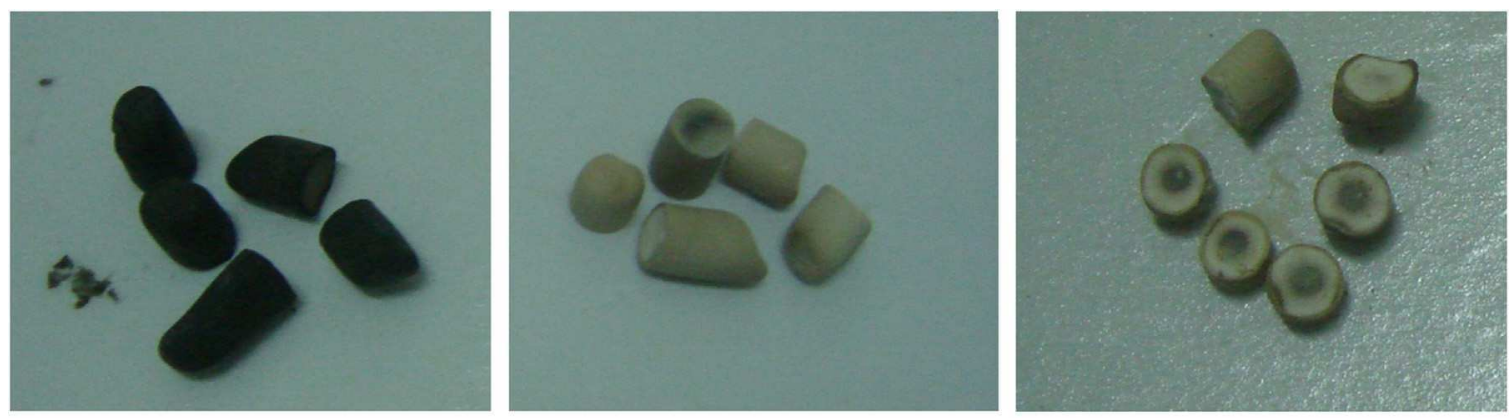

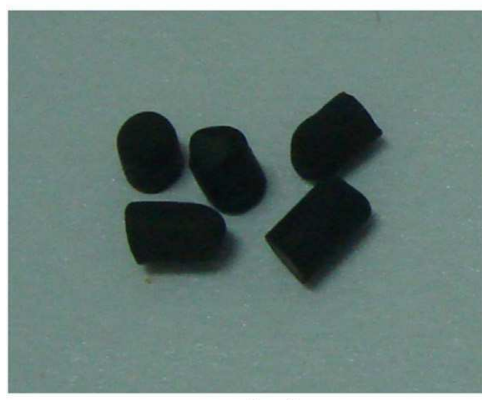

(a)

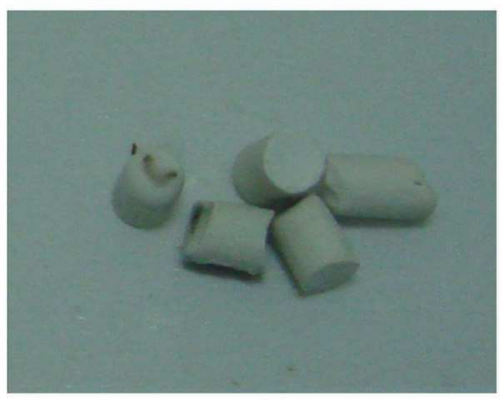

(b)

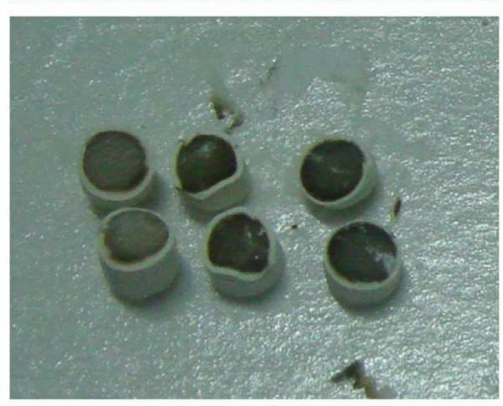

(c)

Fig. 9. Photos of pellets (a) before and (b, c) after regeneration $\left(Q_{\mathrm{G}}=12.7 \mathrm{l} / \mathrm{h}, \mathrm{C}_{\mathrm{O}_{3}, \mathrm{in}}=48 \mathrm{~g} / \mathrm{m}^{3}, \mathrm{TOS}=1 \mathrm{~h}\right)$ : top pictures: $T_{\text {outlet }}=95^{\circ} \mathrm{C}$, bottom pictures: $T_{\text {outlet }}=140^{\circ} \mathrm{C}$.
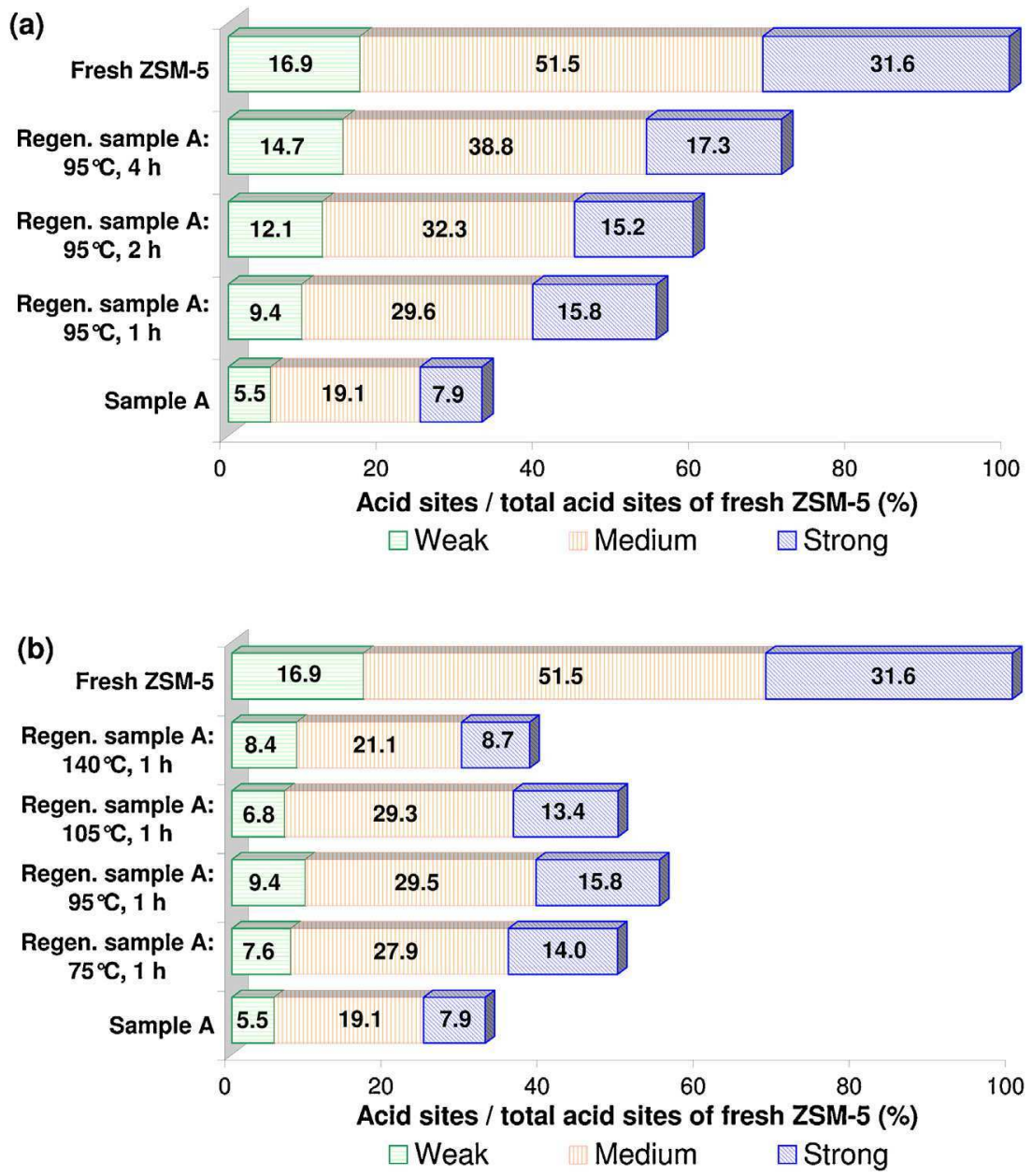

Fig. 10. Distribution of acid sites for fresh zeolite, coked and regenerated samples A: (a) influence of regeneration duration, (b) influence of regeneration temperature. 
Table 3

Acid properties of zeolite extrudates by pyridine adsorption method.

\begin{tabular}{|c|c|c|c|c|c|c|}
\hline \multirow[t]{2}{*}{ Pyridine desorption temperature $\left({ }^{\circ} \mathrm{C}\right)$} & \multicolumn{2}{|c|}{ Fresh zeolite extrudate } & \multicolumn{2}{|l|}{ Sample A } & \multicolumn{2}{|c|}{$\begin{array}{l}\text { (Partially) regenerated sample } \\
\mathrm{A}\left(95^{\circ} \mathrm{C}, 2 \mathrm{~h}\right)\end{array}$} \\
\hline & $\begin{array}{l}\text { Brønsted sites } \\
(\mu \mathrm{mol} / \mathrm{g})\end{array}$ & $\begin{array}{l}\text { Lewis sites } \\
(\mu \mathrm{mol} / \mathrm{g})\end{array}$ & $\begin{array}{l}\text { Brønsted sites } \\
(\mu \mathrm{mol} / \mathrm{g})\end{array}$ & $\begin{array}{l}\text { Lewis sites } \\
(\mu \mathrm{mol} / \mathrm{g})\end{array}$ & $\begin{array}{l}\text { Brønsted sites } \\
(\mu \mathrm{mol} / \mathrm{g})\end{array}$ & $\begin{array}{l}\text { Lewis sites } \\
(\mu \mathrm{mol} / \mathrm{g})\end{array}$ \\
\hline 150 & 599 & 219 & 374 & 136 & 562 & 202 \\
\hline 250 & 529 & 151 & 325 & 104 & 498 & 128 \\
\hline 350 & 419 & 124 & 273 & 94 & 396 & 107 \\
\hline
\end{tabular}

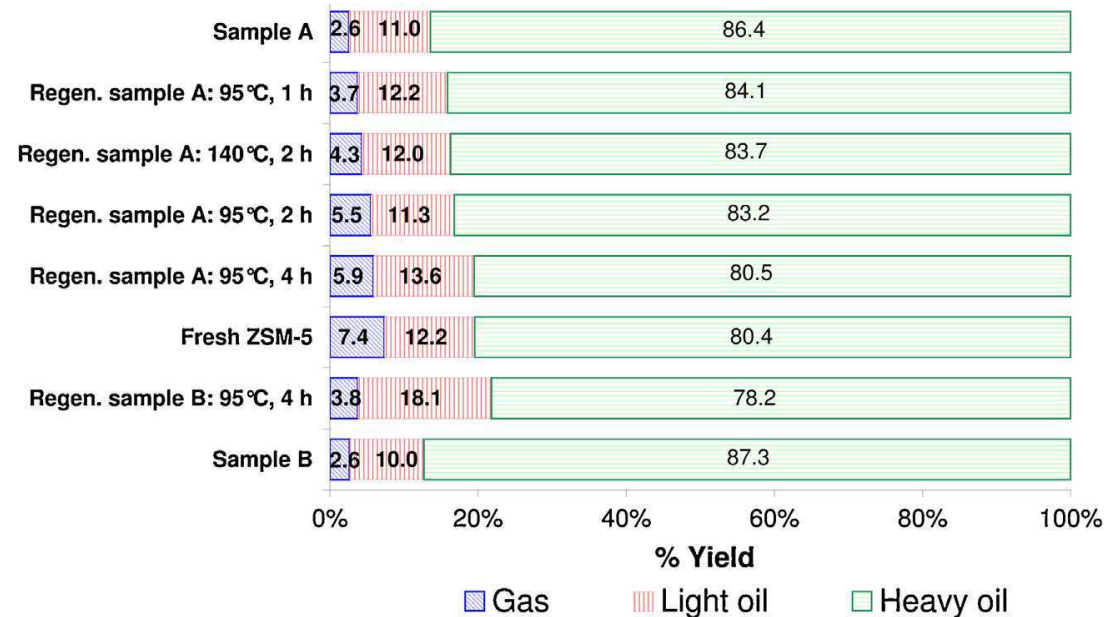

Fig. 11. PMMA degradation yields: distribution of gas, liquid and solid products.

As expected, the longer the regeneration, the higher the recovery of total acid sites, up to $71 \%$ of that of fresh catalyst after $4 \mathrm{~h}$ at $95^{\circ} \mathrm{C}$ (Fig. 10a). In more details, TPD spectra deconvolution showed that time on stream mainly affected weak and medium acid sites, while the quantity of strong acid sites reached a quasi-plateau after $60 \mathrm{~min}$. This level off of acidity restoration complied with the trend shown in Fig. 6a for carbon conversion. Thus the refractory coke fraction mainly blocked stronger acid sites, which are also known to promote oligomerization and condensation reactions [30].

The increase of the regeneration temperature from 80 to $100^{\circ} \mathrm{C}$ (Fig. 10b) improved the recovery of zeolite acidity. On the other hand, a further increase of the outlet temperature from 100 to $140^{\circ} \mathrm{C}$ decreased the amount of all acid sites. Again this result matched well with the carbon removal performance.

From pyridine adsorption results, Table 3 , it can be concluded that sites able to retain pyridine at $350^{\circ} \mathrm{C}$ in fresh catalyst were mainly of Brønsted type and they should represent main fraction of medium and strong acid sites. The amount of total acid sites measured by this method was however lower than that from $\mathrm{NH}_{3}-$ TPD. The difference between both techniques might be explained by a lower accessibility of pyridine to the microporous material due to its larger molecular size [31]. Moreover the pyridine method measured the remaining acid sites after desorption at $150^{\circ} \mathrm{C}$, while for $\mathrm{NH}_{3}$-TPD desorption started at a lower temperature (around $50^{\circ} \mathrm{C}$ ) and therefore weaker acid sites were accounted for by the integration of the desorbed $\mathrm{NH}_{3}$ amount.

The pyridine results also suggest that both Brønsted and Lewis acid sites (estimated from desorption at $150^{\circ} \mathrm{C}$ ) were in similar amounts on the partially regenerated catalyst at $95^{\circ} \mathrm{C}$ and on the fresh one (less than $10 \%$ difference). Moreover, the amount of total acid sites on sample $A$ (prior to regeneration) would be about $60 \%$ of that on fresh ZSM-5, Lewis and Brønsted sites being equally affected. This too optimistic result with respect to $\mathrm{NH}_{3}-\mathrm{TPD}$ might be here explained by a partial desorption of coke molecules from acid sites caused by pyridine, as previously reported [27].
Nevertheless the two techniques agree in that the $2 \mathrm{~h}$ ozonation at $95^{\circ} \mathrm{C}$ restored about $30 \%$ of original acid sites.

\subsection{2. $P M M A$ degradation results}

Fig. 11 compares the distribution of products from PMMA cracking obtained when using the different zeolite catalysts: fresh, coked (samples $A$ and $B$ ), and after regeneration (varying TOS, as well as outlet temperature).

After drying, the weight of solid - including catalyst - was in the range $0.39-0.43 \mathrm{~g}$ for all experiments: solid products accounting for less than $0.1 \%$ of the initial PMMA weight were not accounted for in the balance. The conversion of PMMA was thus considered total. The light oil was mainly composed of MMA, while heavier liquid products were $\mathrm{C} 6-\mathrm{C} 16$ (consisting in aliphatic, alicyclic as well as aromatic compounds, most of them being oxygenated: dimethyl esters, carboxylic acids).

As expected from the acidity and carbon removal results, increasing the regeneration duration improved the zeolite selectivity towards light hydrocarbons. After $4 \mathrm{~h}$ ozonation at $95^{\circ} \mathrm{C}$, the regenerated zeolite gave almost the same (gas + light liquid) yield as the fresh one, yet with a smaller contribution of the gaseous compounds (especially for sample $B$ ). As previously shown, a temperature of $95^{\circ} \mathrm{C}$ was better than $140^{\circ} \mathrm{C}$ to restore the catalyst activity, but again main change was found in the gas yield.

Therefore the differences in medium and strong acid sites observed between fresh and best regenerated zeolites affected only the ultimate stages of the cracking process, what should not be detrimental for the continuous process.

\section{Conclusion}

Regeneration of coked ZSM-5 extudates of $3 \mathrm{~mm}$ diameter was successfully achieved using an ozone-enriched oxygen stream at about $100^{\circ} \mathrm{C}$ : up to $80 \%$ of the coke was removed, restoring specific surface area and $70 \%$ of acid sites. No dealumination was observed. 
The acidity properties and gas yield in PMMA cracking followed the trends observed for the carbon removal efficiency.

The decoking rate was improved by an increase of $\mathrm{O}_{3}$ concentration in the investigated range $\left(16-50 \mathrm{~g} / \mathrm{m}^{3}\right)$. Using a temperature higher than $100^{\circ} \mathrm{C}$ was not beneficial due to the strong limitation of ozone diffusion which confined radical production - thus the regeneration process - to the outer surface.

Regeneration would be thus better performed for smaller particles, but the results were already very promising: the best regenerated sample $\left(4 \mathrm{~h}\right.$, about $\left.100^{\circ} \mathrm{C}\right)$ exhibited a similar activity as the fresh catalyst in PMMA cracking.

\section{Acknowledgements}

The Office of the Higher Education Commission of Thailand and the French Embassy in Thailand are gratefully acknowledged for providing financial support to Supaporn Khangkham through the program Strategic Scholarships for Frontier Research Network.

The authors also thank J.L. Labat, J.L. Nadalin, I. Coghe, V. Loisel and A. Müller (LGC) for technical assistance on the set-up, M.L. de Solan Bethmale, C. Rey-Rouch, G. Raimbeaux (SAP, LGC), P. Jame, A. Bonhomme (SCA, Lyon), L. Pinard and J.D. Comparot (IC2MP, Poitiers) for characterization of the zeolites.

\section{References}

[1] J. Weitkamp, L. Puppe, Catalysis and Zeolite: Fundamentals and Applications, Springer-Verlag, Berlin, Heidelberg, 1999.

[2] P.H. Schipper, F.G. Dwyer, P.T. Sparrell, S. Mizrahi, J.A. Herbst, Zeolite ZSM-5 in fluid catalytic cracking: performance, benefits, and applications, fluid catalytic cracking, chapter 5, ACS Symposium Series 375 (1988) 64-86.

[3] D.P. Serrano, J. Aguado, J.M. Escola, Industrial and Engineering Chemistry Research 39 (2000) 1177-1184

[4] A. Lopez, I. de Marco, B.M. Caballero, A. Adrados, M.F. Laresgoiti, Waste Management 31 (2011) 1852-1858.

[5] S. Khangkham, PhD thesis, Chulalongkorn University/INP Toulouse, 2012.
[6] W. Kaminsky, J. Franck, Journal of Analytical and Applied Pyrolysis 19 (1991) 311-318.

[7] W. Kaminsky, M. Predel, A. Sadiki, Polymer Degradation and Stability 85 (2004) $1045-1050$.

[8] W. Kaminsky, H. Schmidt, C.M. Simon, Macromolecular Symposia 152 (2000) 191-199.

[9] G. Lopez, M. Artetxe, M. Amutio, G. Elordi, R. Aguado, M. Olazar, J. Bilbao, Chemical Engineering and Processing 49 (2010) 1089-1094

[10] N. Rahimi, R. Karimzadeh, Applied Catalysis A 398 (2011) 1-17.

[11] P. Magnoux, M. Guisnet, Applied Catalysis 38 (1988) 341-352.

[12] K. Moljord, P. Magnoux, M. Guisnet, Applied Catalysis A 121 (1995) 245-259.

[13] G.A. Doka Nassionou, P. Magnoux, M. Guisnet, Microporous and Mesoporous Materials 22 (1998) 389-398.

[14] D.P. Ivanov, V.I. Sobolev, G.I. Panov, Applied Catalysis A 241 (2003) 113-121.

[15] F. Ferreira Madeira, K. Ben Tayeb, L. Pinard, H. Vezin, S. Maury, N. Cadran, Applied Catalysis A 443-444 (2012) 171-180.

[16] R.G. Copperthwaite, G.J. Hutchings, P. Johnston, S.W. Orchard, Journal of the Chemical Society, Faraday Transactions 182 (1986) 1007-1017.

[17] P. Monneyron, S. Mathe, M.H. Manero, J.N. Foussard, Chemical Engineering Research and Design 81 (2003) 1193-1198.

[18] L. Mariey, J. Lamotte, T. Chevreau, J.C. Lavalley, Reaction Kinetics and Catalysis Letters 59 (1996) 241-246.

[19] G.J. Hutchings, R.G. Copperthwaite, T. Themistocleous, G.A. Foulds, A.S. Bielovitch, Applied Catalysis 34 (1987) 153-161.

[20] F. Bauer, H.G. Karge, Molecular Sieves 5 (2007) 249-364.

[21] S. Brunauer, P.H. Emmett, E. Teller, Journal of the American Chemical Society 60 (1938) 309-319.

[22] E.P. Barrett, L.G. Joyner, P.P. Halenda, Journal of the American Chemical Society 73 (1951) 373-380

[23] G. Horvath, K. Kawazoe, Journal of Chemical Engineering of Japan 16 (1983) 470-475.

[24] G. Elordi, M. Olazar, M. Artetxe, P. Castano, J. Bilbao, Applied Catalysis A: General 415-416 (2012) 89-95.

[25] C. Ngamcharussrivichai, P. Wu, T. Tatsumi, Journal of Catalysis 227 (2004) 448-458.

[26] G.V.A. Martins, G. Berlier, C. Bisio, S. Coluccia, H.O. Pastore, L. Marchese, Journal of Physical Chemistry C 112 (18) (2008) 7193-7200.

[27] D. Meloni, D. Martin, P. Ayrault, M. Guisnet, Catalysis Letters 71 (2001) 213-217.

[28] B. Wang, G. Manos, Journal of Catalysis 250 (2007) 121-127.

[29] J. Aguado, D.P. Serrano, J.M. Escola, Industrial and Engineering Chemistry Research 47 (2008) 7982-7992.

[30] G. Elordi, M. Olazar, G. Lopez, P. Castano, J. Bilbao, Applied Catalysis B: Environmental 102 (2011) 224-231.

[31] R. Lü, H. Tangbo, Q. Wang, S. Xiang, Journal of Natural Gas Chemistry 12 (2003) $56-62$. 